\title{
Sosialisasi Pembuatan Tanaman Obat Keluarga (TOGA) pada Masyarakat Kepulauan Lemukutan Kalimantan Barat dalam Usaha Penanggulangan Penyakit Demam Berdarah Dengue (DBD)
}

\author{
Desriani Lestari $^{1 *}$ Yanieta Arbiastutie $^{2}$, Warsidah ${ }^{3}$, Shifa Helena ${ }^{3}$ \\ ${ }^{I}$ Program Studi Pendidikan Dokter, FKIK, Universitas Tanjungpura Pontianak \\ ${ }^{2} J u r u s a n$ Teknologi Hasil Hutan, Fakultas Kehutanan, Universitas Tanjungpura Pontianak \\ ${ }^{3}$ Pogram Studi Ilmu Kelautan, Fakultas MIPA, Universitas Tanjungpura Pontianak \\ * Correspondent Author: shifahelena@fmipa.untan.ac.id
}

\begin{abstract}
ABSTRAK
Demam Berdarah Dengue (DBD) adalah penyakit yang disebabkan oleh virus Dengue, banyak terjadi di wilayah tropis ataupun subtropis. DBD banyak berjangkit pada anak usia 5-16 tahun, dengan gejala demam tinggi, perdarahan lalu syok berujung pada kematian dalam waktu singkat. Usaha pencegahan adalah dengan pembersihan genangan air, pengurasan atau fogging, penggunaan anti nyamuk bakar, lotion, fogg terutama pagi dan sore hari. Jika positif terjangkit segera dirawat di rumah sakit serta mengkonsumsi obat-obatan penurun demam, bahan alam yang dapat meningkatkan kadar trombosit darah serta banyak minum air. Tanaman Obat Keluarga yang disingkat TOGA adalah sejumlah tanaman yang dipelihara di pekarangan, berkhasiat obat, dapat memenuhi keperluan obat-obatan sekeluarga dan mewujudkan kemandirian keluarga dalam pengobatan penyakit. Zodia, sere wangi, daun selasih dan lavender merupakan tanaman pengusir nyamuk karena bau yang tidak disukai oleh nyamuk, dapat digosokkan langsung ke kulit atau menempatkan pot tanaman tersebut di area aktivitas kita. Kegiatan pengabdian kepada masyarakat (PKM) ditempatkan di Pulau Lemukutan Kalimantan Barat untuk mensosialisasikan pembuatan TOGA khususnya tanaman untuk pencegahan dan pengobatan penyakit DBD. Kegiatan diikuti oleh 25 orang warga, selanjutnya akan menjadi duta-duta TOGA di seluruh kepulauan Lemukutan.
\end{abstract}

Kata Kunci: Aedes Aegepty, Demam Berdarah Dengue, Fogging, PKM, TOGA

\section{cc) (†)}

This is an open-acces article distributed under the terms of the Creative Commons Attribution-ShareAlike 4.0 International License.

\section{PENDAHULUAN}

Penyakit DBD adalah salah satu penyakit yang berpotensi mewabah di wilayah tropis ataupun subtropis. Lebih dari 100 negara di dunia sekarang ini, menjadi area endemik penyakit DBD yang sebelum tahun 1970 hanya dialami oleh 9 negara. Sebanyak 5 propinsi yang memiliki Incidence Rate (IR) per 100.000 orang penduduk tertinggi adalah Propinsi Bali, Kalimantan Timur, Kalimantan Utara, Kalimantan Barat dan Kepulauan Riau dengan nilai IR masing-masing sebesar 204,20\%, 131,10\%, $128,50 \%, 111,10 \%$ dan 92,60\% (DepKes, 2016). 


\section{Journal of Community Engagement in Health}

http://jceh.org

https://doi.org/10.30994/jceh.v4i2.148

ISSN: 2620-3758 (print); 2620-3766 (online)

Vol. 4 No 2. Sep 2021. Page. 298-302

Salah satu Program Pencegahan dan Penanggulangan Penyakit Menular adalah penanggulangan penyakit DBD, yang sangat penting dilaksanakan mengingat penyakit ini sangat cepat dan mudah mewabah (endemic). Vaksin pencegahan penyakit DBD masih dalam penelitian ditemukan, sedangkan vektor penyakitnya menyebar luas di lingkungan masyarakat, terutama wilayah yang kepadatan penduduknya sangat tinggi. Sebagai langkah nyata perhatian pemerintah dalam penanganan penyakit ini dikeluarkanlah Program Pencegahan dan Penanggulangan Penyakit DBD (DepKes RI 2016).

Keberhasilan dalam usaha penanggulangan penyakit DBD tergantung pada keterlibatan dan sinergitas seluruh kalangan masyarakat dan pemerintah, kecakapan dan keterampilan Sumber Daya Manusia (SDM), kelayakan ketersediaan sarana serta prasarana dalam pelayanan kesehatan prima yang berorientasi ke masyarakat. Kenyataannya, bahwa pada saat ini peran tersebut masih terbilang kurang efektif dan efisien yang menimbulkan angka penderita penyakit ini masih sangat tinggi dan terjadi hampir di sepanjang tahun.

Pulau Lemukutan yang berada di wilayah Kabupaten Bengkayang, berjarak sekitar $17 \mathrm{~km}$ dari daratan pesisir Bengkayang, waktu tempuh perjalanan sekitar 45 menit - 1 jam menggunakan perahu penumpang antar pulau-pulau terdekat. Beberapa kasus penyakit DBD dilaporkan dari tahun 2010-2020 yang berjangkit di pulau tersebut, selain mungkin disebabkan oleh kepadatan penduduk di beberapa wilayah pulau, kemungkinan adanya curah hujan tinggi di masa-masa tertentu menyebabkan tingginya kelembaban di beberapa area dan menjadi media perkembangbiakan nyamuk Aedes aegepty. Jarak tempuh yang lama, dan keterbatasan angkutan penumpang dari pulau ke daratan, menjadi masalah besar jika sewaktu-waktu ada insiden penderita DBD yang memerlukan perawatan atau penanganan khusus. Hal ini mendorong dilakukannya kegiatan PKM Dosen UNTAN ke wilayah kepulauan tersebut dalam mensosialisasikan penyediaan tanaman obat keluarga (TOGA) sebagai usaha pencegahan berjangkitnya penyakit DBD dan sekaligus pertolongan pertama pada penderita penyakit DBD kepada mitra PKM yaitu masyarakat wilayah Lemukutan. Beberapa tanaman herba memiliki aroma khas dan menyebabkan nyamuk pergi menjauhinya antara lain adalah Zodia, lavender, sereh wangi dan daun selasih. Tanaman jenis ini dapat mengusir nyamuk dengan cara menggosok daunnya dan menempelkan atau menggosokkan ke kulit, terutama di pagi hari dan sore hari, saat aktivitas nyamuk meningkat. Di samping itu, ada beberapa tanaman yang dapat dikonsumsi jika terjangkit wabah DBD seperti kunyit, jeringau merah, miyana, jambu biji dan beberapa tanaman lain. Tujuan kegiatan ini untuk menambah pengetahuan dan kemampuan mitra dalam usaha penanganan penyakit DBD, mengklaifikasikan tanaman obat yang secara empiris telah digunakan dalam pencegahan dan pengobatan penyakit DBD serta dapat menjadi kader RT dalam penyebarluasan informasi tentang hal tersebut.

\section{BAHAN DAN METODE}

Pelaksanaan kegiatan PKM bertopik Sosialisasi Pembuatan Tanaman Obat Keluarga (TOGA) pada Masyarakat Kepulauan Lemukutan Kalimantan Barat) terdiri dari beberapa tahapan antara lain :

1. Survei Lokasi dan Perizinan

Lokasi kegiatan ditempatkan di pulau Lemukutan dan survey berdasarkan informasi data penderita DBD sebelumnya. Selanjutnya dilakukan perizinan dengan pemerintah setempat dalam menentukan jadwal pelaksanaan dan tokoh masyarakat atau remaja masyarakat yang akan diundang dalam kegiatan.

2. Penyiapan Alat dan Bahan

Peralatan dan bahan pembuatan TOGA antara lain cangkul dan sekop tanah, bibit bunga zodia, lavender, selasih dan sereh wangi, sirih hijau, sirih merah, serta tanaman berimpang seperti kunyit, jahe, dan bangle serta rimpang-rimpang tanaman lainnya.

3. Penyiapan Materi Ceramah terkait dengan Penyakit DBD dan usaha penanggulangannya, design poster \& materi pelatihan, sosialisasi dan demonstrasi dalam memilih tanaman obat untuk penanggulangan penyakit DBD.

4. Kegiatan dihadiri oleh 25 peserta dari perwakilan 5 RT masing-masing 5 orang. Kegiatan pembuatan TOGA percontohan dilakukan di halaman Balai Rakyat, dan perwakilan masing-masing RT akan menjadi kader perwakilan dalam menanggulangi penyakit DBD, serta berperan dalam 


\section{Journal of Community Engagement in Health}

http://jceh.org

ISSN: 2620-3758 (print); 2620-3766 (online)

https://doi.org/10.30994/jceh.v4i2.148

Vol. 4 No 2. Sep 2021. Page. 298-302

mensosialisasikan, merencanakan dan memonitor pelaksanaan kegiatan pembuatan TOGA di pulau tersebut.

5. Selanjutnya tahapan terakhir adalah adokumentasi dan evaluasi pelaksanaan kegiatan serta pelaporan hasil kegiatan. Untuk Evaluasi, Pembagian angket atau pre test serta post test menjadi indikator sementara keberhasilan pelaksanaan program PKM ini, sedangkan indikator dalam jangka waktu lama adalah tersedianya TOGA di pekarangan rumah masing-masing warga.

\section{HASIL}

Peserta kegiatan PKM sebanyak 25 orang yang merupakan perwakilan dari 5 RT di Desa Lemukutan, masing-masing RT mengirimkan utusan yang terdiri secara acak perempuan dan pria serta umur remaja sampai dewasa. Setiap peserta perwakilan RT diharapkan untuk bisa menjadi kader dalam mensosialisasikan informasi-informasi penting terkait penyakit DBD dan program TOGA ini kepada masyarakat lainnya, sehingga pada akhirnya terwujud kemandirian masyarakat dalam pencegahan penyakit DBD, dan dalam meningkatkan system imunitas sehingga tidak mudah terserang jika sedang terjadi wabah DBD.

Tim Dosen Universitas Tanjungpura telah melakukan kegiatan PKM dari pulau Lemukutan yang secara garis besarnya dibagi dalam 3 kegiatan, yaitu ceramah dengan materi tentang pengenalan penyakit DBD dan cara mencegah serta mengobati jika terpapar wabah DBD, membuat poster yang sifatnya mengedukasi warga masyarakat agar selalu meningkatkan kesadaran dan kewaspaan terkait penyakit DBD di masa-masa tertentu dan membuat TOGA untuk restock tanaman obat yang dapat digunakan dalam pencegahan DBD dan sekaligus tanaman yang dapat meningkatkan system imun selama terjangkit DBD.

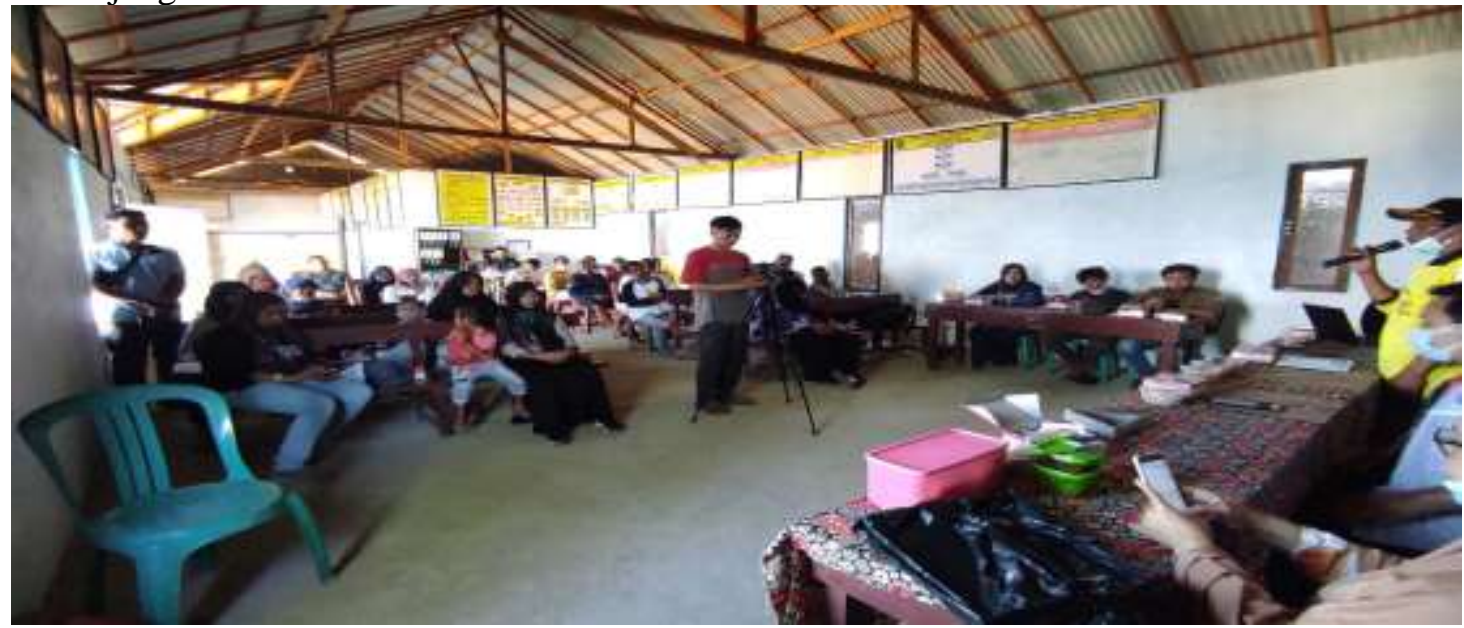

Gambar 1. Kegiatan ceramah dengan materi tentang penyakit DBD, gejala dan penanganannya.

Materi ceramah tentang penyakit DBD ini dimaksudkan agar seluruh lapisan masyarakat meningkatkan kesadaran dan kewaspadaan terhadap wabah DBD terutama dalam masa-masa tertentu. Siklus mewabahnya atau cara penularan penyakit DBD dapat digambarkan sebagai berikut :

Penderita Virus dengue $\rightarrow$ tergigit oleh Nyamuk Aedes $s p \rightarrow$ virus masuk lambung Aedes $s p \rightarrow$ virus menyebar ke jaringan nyamuk termasuk liur $\rightarrow$ nyamuk menggigit dan menularkan ke orang lain $\rightarrow$ Virus akan berada dlm tubuh nyamuk selamanya.

\section{PEMBAHASAN}

Propinsi Kalimantan Barat menempati peringkat ke 4 dari 5 propinsi dengan nilai Incidence Rate (IR) tertinggi endemik penyakit DBD yaitu sebesar $111,10 \%$, setelah Bali, Kaimantan Timur dan Kalimantan Utara. Khusus di wilayah Kalimantan Barat pada tahun 2015 dilaporkan, Kabupaten Ketapang, Sintang, Kubu Raya, Kota Pontianak dan Kayong Utara menjadi 5 kota/kabupaten tertinggi nilai IR nya. Beberapa penelitian telah dilakukan di beberapa wilayah Kalimantan Barat yang melaporkan kejadian luar biasa tentang penderita DBD ini (DinKes Propinsi, 2016). Penyebaran 


\section{Journal of Community Engagement in Health}

http://jceh.org

ISSN: 2620-3758 (print); 2620-3766 (online)

https://doi.org/10.30994/jceh.v4i2.148

Vol. 4 No 2. Sep 2021. Page. 298-302

penyakit DBD sangat ditunjang oleh kondisi lingkungan pemukiman masyarakat. Dengan berbagai jenis kondisi lingkungan di masing-masing desa yang ada di Kalimantan Barat ini, tentunya mempengaruhi prevalensi berjangkit dan mewabahnya penyakit DBD. Untuk itu perlu ada usaha pemerintah yang bersinergi dengan seluruh kalangan masyarakat untuk meningkatkan kewaspadaan dan kesadaran bersama terkait penyakit DBD terutama saat musim hujan dan setelahnya.

Kepulauan Lemukutan terletak di wilayah Kabupaten Bengkayang, meskipun tidak masuk dalam 5 besar kabupaten dengan IR tertinggi di Kalimantan Barat, tapi beberapa kasus DBD dilaporkan dari wilayah-wilayah pelosoknya. Kepulauan Lemukutan merupakan gugusan pulau-pulau kecil seperti Randayan, Penata Kecil, Penata Besar dan Kabung yang ditempuh dari daratan selama sekitar 45 menit perjalanan menggunakan perahu angkutan umum khusus dari pulau ke pulau di gugusan kepulauan tersebut. Hampir tiap tahun selama tahun 2010 sampai saat ini, selalu ada laporan pasien DBD dari pulau, walaupun tidak menjadi kasus KLB tetapi sangat penting untuk mendapatkan perhatian dalam mencegah mewabahnya DBD di pulau-pulau tersebut, mengingat kesulitan transportasi yang beresiko jika ada insiden luar biasa.
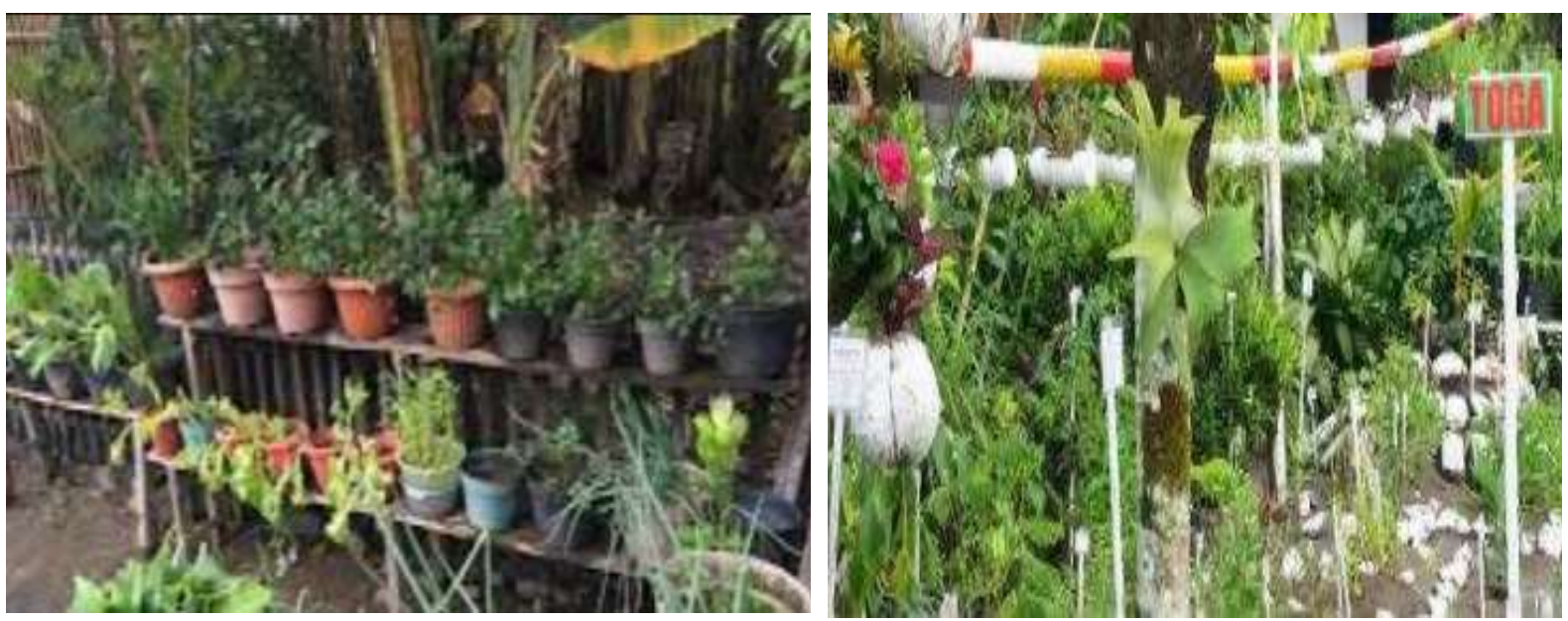

Gambar 2. Pemanfaatan tanah pekarangan masyarakat untuk TOGA

Suhu udara berhubungan erat dengan kondisi kelembaban udara, di mana jika suhu udara rendah, maka kelembaban udara menjadi semakin tinggi. Suhu udara berada pada kisaran $26^{\circ} \mathrm{C}-28,5^{\circ} \mathrm{C}$, adalah suhu optimal untuk kehidupan nyamuk Aedes $s p$ dan menunjang dalam meningkatkan kasus DBD. Penelitian yang sama oleh Nisaa A, dkk (2016), jika udara bersuhu kurang dari $26^{\circ} \mathrm{C}$ dan ataupun lebih dari $28,5^{\circ} \mathrm{C}$ atau jika di atas $35^{\circ} \mathrm{C}$ kasus DBD akan berkurang karena proses fisiologis dari nyamuk Aedes sp nya mengalami perlambatan. Pada hasil uji hubungan antara suhu dengan kejadian DBD menunjukkan korelasi negatif yang berarti bawha jumlah kasus DBD akan mengalami peningkatan sebanding dengan menurunnya suhu udara, dan semakin lembab atau rendahnya suhu udara dari suatu lingkungan pemukiman, maka akan meningkat pula kasus penyakit DBD. Di sisi lain, adanya curah hujan yang tinggi akan meningkatkan kasus DBD karena akan berpengaruh terhadap suhu udara juga, terutama di musim kemarau yang biasanya sampah buangan menumpuk sehingga pada saat masuk musim hujan akan menjadi tempat yang sangat baik untuk perkembangan nyamuk Aedes sp. Korelasi hubungan yang cenderung positif menunjukkan bahwa setiap kenaikan curah hujan diikuti dengan naiknya jumlah kasus DBD (Yasin,M,. 2012). Kegiatan lain yang masih serangkaian dengan pelaksanaan PKM ini adalah mendesign dan membuat poster-poster tentang penyakit DBD untuk ditempel di layanan-layanan umum seperti puskesmas, sekolah-sekolah dan kantor pemerintah desa agar selalu mewaspadai datangnya wabah DBD ini.

Selain itu dijelaskan bahwa penyebab utama mewabahnya kasus DBD adalah faktor lingkungan baik fisik, biologis, maupun sosial yang dapat mempengaruhi transmisi penyebaran virus dari vektor Dengue (WHO, 2011). Berdasarkan hasil penelitian yang dilakukan oleh Abdullah, AZ., dkk (2010) bahwa salah satu faktor dominan terhadap mewabahnya DBD adalah kondisi lingkungan fisik pemukiman, seperti kepadatan penduduk dalam lingkungan perumahan, kebiasaan masyarakat 


\section{Journal of Community Engagement in Health}

http://jceh.org

https://doi.org/10.30994/jceh.v4i2.148

ISSN: 2620-3758 (print); 2620-3766 (online)

Vol. 4 No 2. Sep 2021. Page. 298-302

menggunakan kelambu atau semprot baygon. Syarif Syauqiannur, dkk (2019) menunjukkan bahwa jika suhu udara di suatu lingkungan rendah, maka kejadian DBD akan meningkat.

Selanjutnya adalah kegiatan sosialisasi pemanfaatan tanah pekarangan masyarakat pulau Lemukutan untuk dijadikan TOGA, selain dimaksudkan untuk menambah pengetahuan masyarakat pulau Lemukutan mengenai manfaat tanaman obat di sekitar kita yang dapat dijadikan pengobatan alternatif sekaligus untuk menjaga kesehatan probadi dan keluarga terutama dalam pencegahan dan pengobatan penyakt DBD. Keberadaan TOGA juga diharapkan dapat mengurangi kuota pengeluaran keuangan keluarga dengan membeli obat-obatan cenderung mahal. Dari angket yang dibagikan dalam kegiatan PKM ini menunjukkan 95\% dari 25 mitra yang ikut langsung telah mengalami peningkatan kemampuan dan pengetahuan penyakit DBD, dari kemampuan rata-rata hanya $60 \%$ dalam memahami tentang penyakit DBD dan penanganannya, meningkat menjadi $95 \%$. Ini merupakan evaluasi kegiatan pelaksanaan selama kegiatan berlangsung, dan indikator keberhasilan program ini dapat ditunjukkan dengan tersedianya TOGA di pekarangan rumah warga, salah satu usaha untuk pertolongan pertama pada keluarga jika ada yang terjangkit wabah tersebut. TOGA harus berisi tanaman-tanaman yang dapat mengusir nyamuk, sehingga menghindarkan kita dari gigitannya seperti Zodia, Lavender, Sereh wangi, Selasih, selain itu berisi tanaman-tanaman yang dapat meningkatkan imunitas tubuh sehingga tidak mudah terserang penyakit seperti kunyit, jahe merah, dan beberapa tumbuhan berimpang lainnya.

\section{KESIMPULAN}

Dari kegiatan pelaksanaan PKM ini dapata disimpulkan sebagai berikut :

1. Terdapat tiga faktor yang berperan penting dalam proses penularan penyakit DBD yaitu manusia, virus dan vektor perantara, sedangkan kepadatan dan kebiasaan penduduk yang tidak hygienis, suhu udara dan curah hujan merupakan faktor pendukung mewabahnya DBD hampir di seluruh wilayah Indonesia.

2. TOGA merupakan salah satu sarana pertolongan pertama untuk keluarga jika terpapar penyakit DBD, sehingga sedapatnya berisi dengan tanaman-tanaman yang dapat mencegah gigitan nyamuk Aedes aegepty, meningkatkan imun sehingga tidak mudah terjangkit penyakit DBD.

\section{REFERENSI}

Abdullah AZ, Nawi R, Sibe A. 2010, Faktor Risiko Kejadian Demam Berdarah Dengue di Kecamatan Tempe Kabupaten Wajo 2009. Media Kesehatan Masyarakat Indonesia.; 6(4):198-203.

Nisaa A, Hartono H, Sugiharto E. Analisis Spasial Dinamika Lingkungan Terkait Kejadian Demam Berdarah Dengue Berbasis Sistem Informasi Geografis Di Kecamatan Colomadu, Kabupaten Karanganyar. 2016, Journal of Information Systems for Public Health.; 1(2):23-8.

Syarif Syauqiannur, Agus Fitriangga, Muhammad Pramulya, 2019, Sebaran kasus dan faktor risiko kejadian DBD berbasis SIG Kabupaten Kubu Raya tahun 2016-2018.

Yasin M. 2012. Hubungan variabilitas iklim (suhu, curah hujan, hari hujan dan kecepatan angin) dengan insiden Demam Berdarah Dengue di Kota Bogor 2004-2011. Depok: Fakultas Kesehatan Masyarakat Universitas Indonesia.

Dinas Kesehatan Provinsi Kalimantan Barat. Profil Kesehatan Provinsi Kalimantan Barat Tahun 2015. Pontianak: Dinas Kesehatan Provinsi Kalimantan Barat; 2016.

Kementerian Kesehatan RI. Kebijaksanaan program P2-DBD dan situasi terkini DBD Indonesia. Jakarta: Kementerian Kesehatan RI; 2016.

World Health Organization, Regional Office for South-East Asia, 2011. Comprehensive guideline for prevention and control of dengue and dengue haemorrhagic fever. New Delhi: World Health Organization, Regional Office for South-East Asia;. 